\title{
A Critical Pragmatic Analysis of Women Oppression
}

\author{
Asst.Prof. Qasim Abbas Dhayef (Phd), University of Babylon, College of Education for Human Sciences, \\ Department of English, qasimabbas@uobabylon.edu.iq \\ Masoumah Abathar Witwit, University of Babylon, College of Education for Human Sciences, Department of \\ English,V78bnkbffe@gmail.com
}

\begin{abstract}
Oxford English Dictionary defines insult as" To assail with offensively dishonoring or contemptuous speech or action; to treat with scornful abuse or offensive disrespect; to offer indignity to; to affront, outrage -perhaps by manifest arrogance, scorn, contempt, or insolence. Meriam Webster's Dictionary defines oppression as unjust or cruel exercise of authority or power. The present study investigates women insulting jokes from a critical pragmatic perspective. Females have been oppressed and underrepresented by jokes and many scholars have stated that joke saying is mainly a male activity (Bing, $2007: 1$ ). The present study investigates women insulting jokes from a critical pragmatic perceptive. It aims at investigating how women are oppressed and insulted through a specific kind of jokes. Al-Hindawi and Mohamad (2018:1) state that using an impolite speech act rather than a polite one falls within the realm of critical Pragmatics. Since insulting jokes as speech acts are used to insult women, the present study falls under the realm of critical pragmatics. The current study is a qualitative one based on analytical model that is developed for the present study. This study is limited to the analysis of nine women insulting jokes. The results of the present study are significant in supporting the notion that critical pragmatic field can investigate the use of insulting jokes for gaining dominance over women.
\end{abstract}

Keywords: women, oppression, analysis.

$\begin{array}{lll}\text { Received: 09.12.2020 } & \text { Accepted: 11.01.2021 } & \text { Published: 03.02.2021 }\end{array}$

\section{Introduction}

The problem of the present study that females are oppressed by insulting jokes. It tries to answer the following questions:

1- How are women oppressed by the use of positive -self presentation and negative other presentation in the selected insulting jokes?

2- What are the impoliteness strategies used in the insulting jokes to oppress women?

3- What are the types of offensive speech act that are used in the selected insulting jokes to oppress women?

4- How are Grice Maxims utilized in the insulting jokes to oppress women? This study aims at the following points:

1- Investigating the use of ideological square's positive self-presentation and negative other presentation in a number of insulting jokes to oppress women.

2- Finding out the impoliteness strategies used in the insulting jokes to oppress women.

3- Pinpointing the types of offensive speech acts that are used in these jokes to oppress women.

4- Identifying the ways in which Grice Maxims are used in these insulting jokes to oppress women.

This study hypothesizes that:

1- The device of positive -self presentation and negative other presentation is used in some English insulting jokes to oppress women.

2- A number of impoliteness strategies are used in these insulting jokes to oppress women.

3- Different Types of offensive speech act are used in the insulting jokes to oppress women.

4- Obedience and violations of Grice Maxims have been used in these insulting jokes to oppress women.

For reaching the aims of this study, the following procedures are presented:

1- Presenting a theoretical background of Critical Pragmatics, insult as a speech act, and oppression.

2- Developing theoretical framework for analysis for analysis based on Van Dijk (1998), Culpeper (1996:355-356), Searle (1975) and Grice (1975). 
3- Analyzing nine selected women insulting jokes' slogans qualitatively based on the developed theoretical framework.

The Limits

The study is limited to the Critical Pragmatic Analysis of only nine slogans that deals with women insulting jokes.

The Significance

The study is significant since it reveals women oppression that is hidden in women insulting jokes and addresses the slogan designers to avoid insulting and oppressing women through jokes.

\section{Theoretical framework of the study : Critical Pragmatics}

Al-Hindawi, and Mohamad (2018) state that critical pragmatics lends us a critical eye to the pragmatic theories and their activation in critical issues. Korta and Perry (2013) affirm that critical pragmatics is the most current view of pragmatic theories pragmatics is critical to linguistic theories. This branch makes sense of every other branch of natural language studies. Korta and Perry (2011) state that critical pragmatics develops and investigates three ideas that are language as a way of doing things with words, meaning of and contents that are taken from human intentions, and language's integration with other aspects to lead humans to gain their communicative aims. This field is different from pragmatics in that it does not deal with the ordinary language use but with language abuse and especially the role of power, dominance and control in language use. Critical pragmatics aims to increase people's awareness and understanding regarding language use and how power, dominance and control are increased through manipulative language use.

According to the American Heritage (student dictionary), a joke is defined as something said or done to cause laughter, especially an amusing story with a punchline. This study deals with one type of jokes that are called offensive jokes. In this regard, Oxford English Dictionary define offense as Annoyance or resentment brought about by a perceived insult to or disregard for oneself or one's standards or principles. Also, The American Heritage (Student Dictionary) defines offence as the act of causing anger, resentment, or displeasure or the state of being offended. In a similar regard, The American Heritage (Student Dictionary) defines insult as to treat with insensitivity or contempt The current study examine how women are insulted or offended by male's jokes. Yule (2000: 3) define pragmatics as the field that deals with the study of meaning as communicated by the speaker or writer and interpreted by a listener. It deals basically with what the speakers do with their utterances rather than what the words or phrases basically means by themselves. This kind of study deals what people mean in a specific context and the influence exerted by the context. It also deals with considerations of the speaker's arrangement of his speech according to a specific time, place, and the circumstances.

Mey (2001: 320) state that it is very significant to investigate the way language functions in the society so we can understand its uses within the society. Pragmatics as social phenomena can help us in recognizing of social injustice or hidden ideologies within language. The social aspects of pragmatics can help in delving language use in the society and to have a critical eye on issues like discrimination, racism, and injustices. Regarding Critical Discourse Analysis (Henceforth: CDA) , Van Dijk (2001: 395) defines CDA as dealing with a type of discourse analytical research used to study and investigate the ways society, power abuse, dominance, and inequality are produced and reproduced in text and talk.

The critical perspective is very significant in CDA in that it relates scholarly enquiry with issues of immediate concern of the society and the non-scholarly world. CDA has developed discourse analysis to deal with a moral cause or to ideological purposes (Widdowson ,2004:89). Regarding critical pragmatics. He also criticizes the way that pragmatics use dealing with the Gricean notion of intentionality and saying that in investigating the intention of the speaker, one should not deal only with aspects such as context, cooperative principles, and implicature but to go beyond all these levels reaching the critical awareness, ideology, and power behind using these pragmatic aspects. He also states that, it is not possible to investigate felicity conditions of speech act only rather than investigating what people can do with these speech acts especially if they are dominant or powerful. Verschueren (1999b: 871-5) addresses the critical aspects of pragmatics and investigates the notion of authority regarding the main concepts in pragmatics

\section{Basic Concepts in Critical Pragmatics Power}


The German sociologist Max Weber (1925: 28) which cited from Kronman (1983:38) define power as the probability that one actor. within a social relationship will be in a position to carry out his own will despite resistance, regardless of the basis on which this probability rests.

Van Dijk (1996:85) explains that social power and dominance are usually organized and institutionalized in order to permit greater effective control and allow and enable the routine types of power reproduction which means that power is successful since it is found in the daily routine activities which are usually not investigated but they are seen as normal.

Baker and Ellece (2011) state that power is people's capacity to control their environment, and also their lives and other people's life. Women are often and in many cases controlled by powerful men and oppressed by them. Men have more social power and dominance and their power is institutionalized. Besides their power and dominance become part of everyday live, for instance, using jokes to insult women and which gradually becomes a normal matter and a natural thing.

\section{Hegemony}

This concept become popular by Gramsci (1975-1985) who explains that it is related to the exercise of power. Everybody in the society is under some kind of control or under dominance. It is possible that the dominated people are unaware of their status in the society and had been persuaded that this is their natural status and position in life or they accept this low statue and being dominated or controlled since they gain some benefits from this situation. Women are in many cases especially in insulting jokes are believed to be inferior to men and women have to take them as only mare jokes. Also women are in many cases convinced to live in inferior position or to endure insulting jokes and they believe that it is natural to live in this way.

\section{Dominance}

Carlo (2013) states that dominance is regarded as power abuse. It refers to actions that are against low, democracy, equality, and justice. It also can be part of everyday life. Gramsci states that dominance is one form of hegemony (Gramsci, 1971). Women regarding insulting jokes in specific and in society in general are mostly dominated by men. All actions that are against low, justice and equality are practiced against them in different aspects of society including the linguistic one. This dominance of men over men is considered as normal and part of the ordinary everyday life. Insulting women in jokes and presenting them as inferior is regarded as normal and acceptable by the society.

\section{The Nature of Insult as a Speech Act}

Insults are words or expressions that used increase the intentional force of communication. Insults are considered as emphatic reflection of our intentions, evidence of our expressions and feelings and a clear indication of humans' aggressive nature. Since insults are regarded as a part of our communication system and part of language, their role is more complicated than it is expected. Insults are regarded as code and etiquette breaking and violating in every possible way and they lead to an immediate response from the hearer. Insults are able to manipulate words to add additional implicit meaning. Insults mainly have a connotative nature and in this respect, they are similar to metaphor and absurd analogies. They are related to innovative use of language like the dead metaphor and the use of insult can lead to the creation of new terms and expressions. Insult can turn in to art and a weapon used by people who are professional like politicians who can insult indirectly and the person who is insulted is not sure whether he has been insulted or not.

There is what is called " insulting literature" which is found in the form of pseudo-humorous pamphlets, rhymes, screen plays. Insulting jokes are usually directed to minorities or people from different race or culture and they are mainly published or said by people who believe themselves to be superior and people who are insulted as inferior. People can compete with each other using oral insults until one wins (Murray, 1983: 190). Oral insults are highly emotionally effective one and are based on well experienced and rehearsed catalogue and insulters choose the most suitable place and time for the insult to be affective (Yus and Mateo ,2000: 1 -2).

Women are oppressed in many cases by insulting jokes that are aimed at producing a negative view regarding women.

\section{Oppression}


The American Heritage (Student dictionary) defines oppressing as to keep down by harsh and unjust treatment.

Cambridge English dictionary defines oppression as a situation in which people are governed in an unfair and cruel way and prevented from having opportunities and freedom.

Women have always been identified as the essence and the center of the society. However, the fact that they are often under discrimination and oppression has limited their skills and abilities. Oppression against women can born from different aspects of society like, social, marital and patriarchal as a nature of society. Women oppression is related to gender discrimination and patriarchy. Patriarchy ideologies are the clearest types of oppression in which men are superior and women are inferior in the society. The notion of oppression is related to the old and historical interpretation of gender which presents men as the power and the assets who have the complete freedom and authority over women (Dickson, 2018:1).

Oppression against women has emerged resulting and relating to power struggle during times when men were ensuring the influent on status ranking and denying women's influence in this ranking. From the oldest times till this century, women are facing different kinds of subjugation and tyranny from the entire society. This is related low access of women to many aspects of society including jobs (ibid).

The current study deals with women oppression in a selected English insulting jokes' slogan.

\section{Methodology}

Research data is analyzed qualitatively or quantitatively or both. Qualitative research is associated to ethnography, case study, and narrative inquiry that deals with a smaller number of participants with more holistic account (Kaplan ,2010:47). The qualitative method is used for the analysis of the data in the present study.

Data that is used in present study consists of nine slogans that are collected from different websites. This data deals with jokes that insult women and oppress them.

The theoretical framework that is developed for the current study consists of the followings:

\section{Ideological Square}

Van Dijk (1998) states that the concept of ideological square is a very significant feature of socio-cognitive approach. It deals with the strategies followed by social groups from different kinds to present themselves positively and to present the other group negatively. It is concerned with the polarization of people's and particularly the media 'discourse that sheds light on the positive actions of the in-group and the negative actions of the out-group. It also de-emphasizes the negative actions of the out-group and the positive actions of the in-group.

\section{Impoliteness}

Culpeper (1996) explains impoliteness and its strategies that are used in different situations. The strategies that are used for expressing impoliteness are as the followings:

\section{A- Bald on Record:}

The basic massage that is expressed in a specific context is impolite without the use of other extra impoliteness strategies.

\section{B- Positive Impoliteness}

This strategy attacks the positive face by viewing the other as unwanted and out of the group besides talking about the other in a negative way.

\section{C-Sarcasm or Mock Politeness}

The speaker is apparently a polite person using politeness strategies but in reality he or she is doing the opposite.

\section{D-Withhold Politeness}

Politeness is ignored or left out when it is expected. For example: not saying hello or how do you do back when someone says is saying hello to you.

\section{3-Offensive Speech Act}

Searle (1975) classify speech acts to five main categories. These categories are assertive, directives, commissives, expressive, and declarations. The offensive speech act can be any of these categories.

\section{C-Cooperative Principles}


Yule (2000:36-37) explains the cooperative principles following (Grice 1975) as the concept of having an expected amount of information that is supplied in a conversation is one aspect of the fact that people that are engaged in a conversation will cooperate with each other. The cooperative principle consists of four maxims as in the followings:

1- "Quantity

Make your contribution as informative as is required (for the current purposes of the exchange).

2- Quality

Try to make your contribution one is true.

Do not say what you believe to be false.

Do not say that for which you lack adequate evidence.

3-Relation Be relevant

4-Manner Be perspicuous" (The cooperative princple and maxims based on (Grice 1975) and quoted from (Yule ,2000:37).

Yule also states that implicature is the additional conveyed meaning in the conversation. Implicatures are instances of more being communicated than is said. For implicatures to be understood, the cooperative principle and its maxims must be operating.

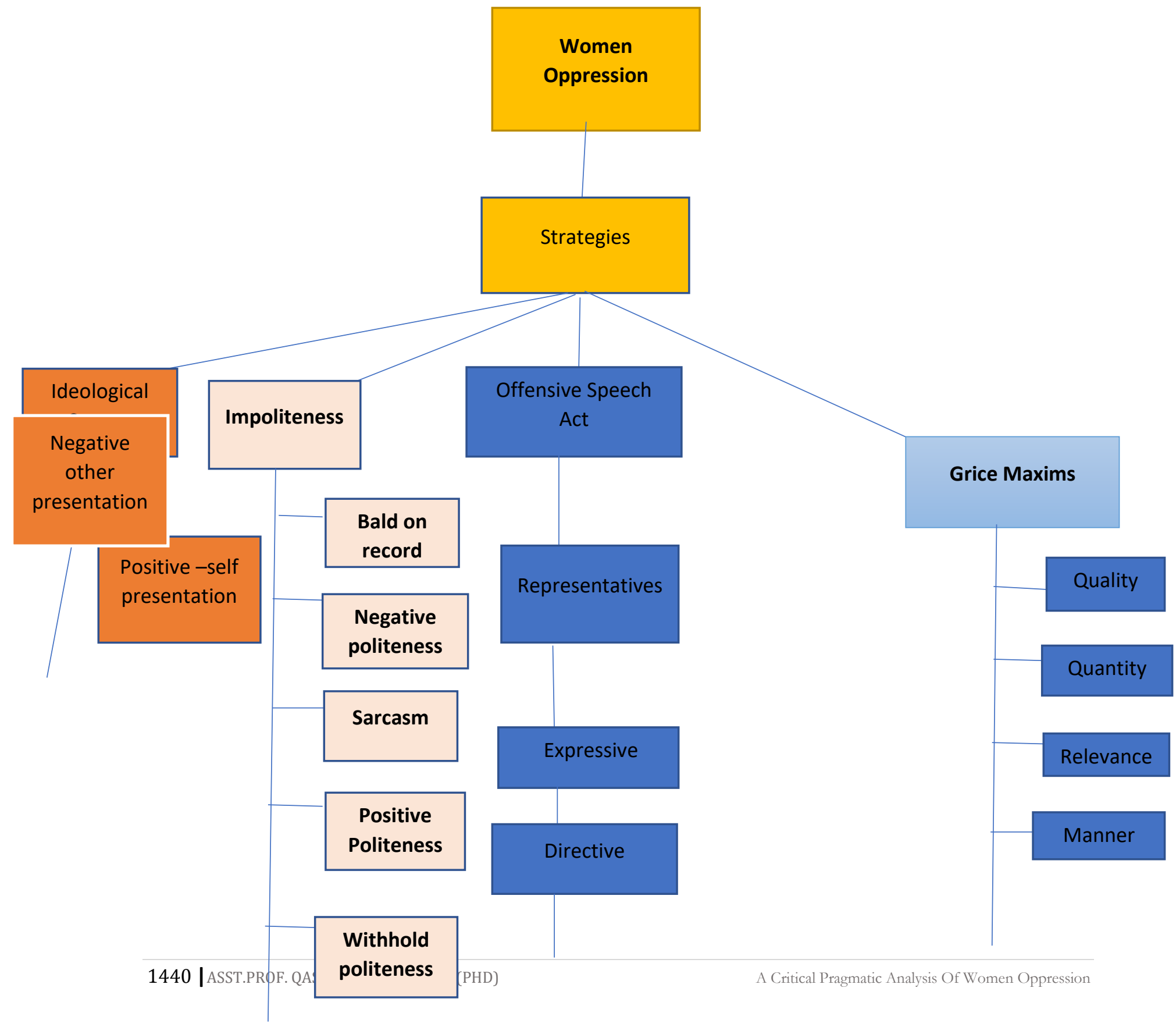




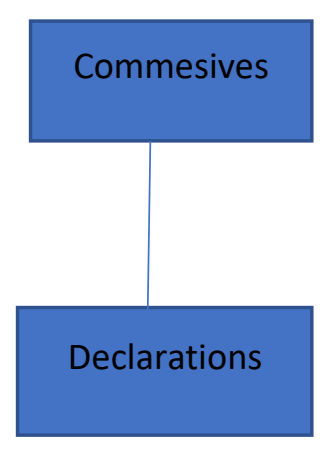

\section{Data Collection and Selection}

The data chosen for the present study is 9 slogans that are considered as funny offensive jokes. They have been collected from different websites. This data was chosen for analysis since it offends women using different pragmatic means that leads to the oppression of women and men dominance.

\section{Data Analysis}

The slogans will be analyzed according to the theoretical model developed for the present study representative speech act, impoliteness, implicature, and ideological square.

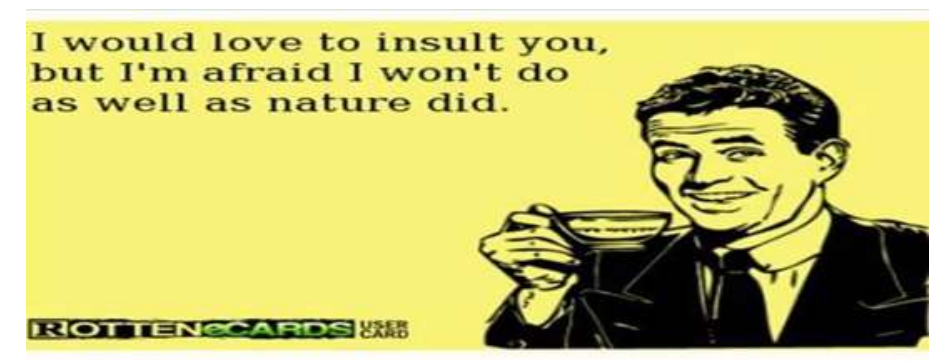

\section{Analysis of the First Slogan}

Regarding offensive speech act, the locutionary act is presented by saying "I would love to insult you, but I 'am afraid that I won't do as well as nature did. Dealing with the illocutionary act, the illocutionary force is expressing. Following Searle (1975), the type of speech act in this slogan is an expressive speech act in which the speaker is expressing his feelings and love of insulting women. The propositional content condition, the slogan address non-specific women expressing his desire to insult her but she has been already insulted by her own self and nature. The preparatory condition in which the man believes in his authority to insult women and the circumstances of insulting women are appropriate for the speech act to be performed. The sincerity condition of this speech act is suitable since it intends seriously and sincerely to insult women. The essential condition is also suitable since this slogan intends that this speech act must affect women to be insulted. Regarding impoliteness following Culpeper (1996: 355-356), the slogan contains two impoliteness strategies that bald on record, and negative impoliteness. Using the bold on record, the basic massage in this slogan is impolite in that it asserts that women are naturally insulted because they are women and do not have enough intelligence. Regarding negative impoliteness, the slogan attacks' women's positive face, since, it treats women as unwanted and inferior and describing women as fools whom are already insulted because of being women. Moving to Grice '(1975) maxims and producing implicature, the slogan breach some of the maxims to express an implicature. The slogan follows the quantity maxims in that the slogan is informative and express a complete massage. The slogan violates the quality maxim in saying something that he does not have full evidence about it and this violation holds an implicature that women are insulted naturally because of having less mental ability than men. This slogan follows the manner and relevance maxims in that the speaker express a clear, ordered, organized insulting massage and it is relevant since it present an insulting massage and not something irrelevant to the subject of insulting. Finally, dealing with Van Dijk's (1989) ideological square of positive -self presentation and negative -other presentation, the slogan is polarized in to positive self-presentation of men by assigning all the positive features to men like intelligence and 
superiority and relating all the negative features to women like foolishness, inferiority and weakness and ignoring all the women's positive features.

\section{Analysis of the Second Slogan}

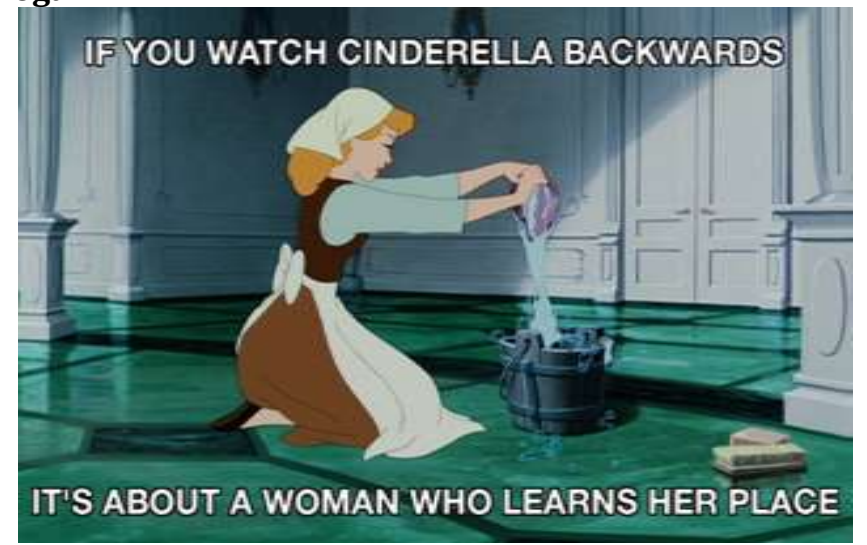

Dealing with offensive speech act, the locutionary act is presented in saying "If you watch Cinderella Backwards, it is about a woman who learns her place". The speech act is representative and the illocutionary force is asserting. Regarding the felicity conditions, the propositional content condition is that the slogan is trying to underestimate women by saying that women like Cinderella must know their place in life. The preparatory condition, the slogan designer believes himself to be in authority position to underestimate and insult women and the circumstances of this speech act which is insulting and humiliating women are appropriate. The sincerity condition, the slogan designer is sincerely and seriously trying to insult women and addresses them as inferior to men by using insulting jokes. Dealing with impoliteness, the slogan uses bold on record in which it's massage is impolite without using any other ways to make it more impolite. The slogan uses positive impoliteness and attacks women's positive face by presenting them as unwanted in the society and humiliating them using insulting jokes. Regarding Grice Maxims, the slogan follows the quantity maxim in that it is informative. The slogan violates the quality maxim, in asserting a notion without giving any evidence for its truth. The slogan violation of this maxim is an implicature which implies that women are inferior to men and must be limited to housekeeping as their only role in life and are not allowed or capable to have a role in the society. The slogan follows the manner and relevance maxims in presenting a massage that is clear, organized and relevant to the subject of women humiliation by using insulting jokes. Finally, dealing with Van Dijk's (1989) ideological square, the slogan is polarized in to positive -self presentation and negative -other presentation. Men are presented positively with all positive features as superior who functions actively in the society while women are presented negatively shedding light on her role as a house keeper and ignoring her competent role in the society.

\section{Analysis of the Third Slogan}

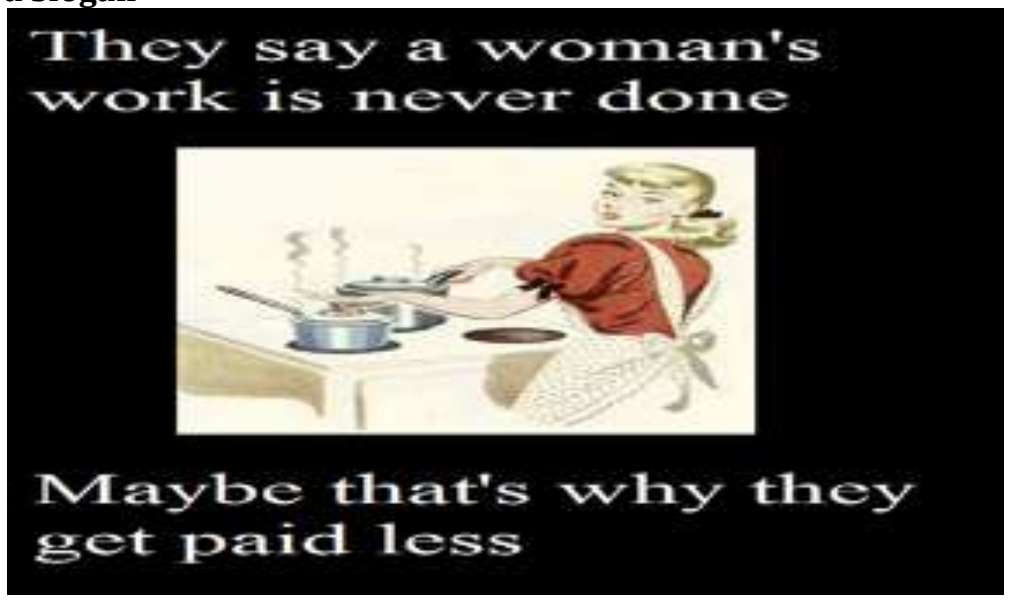


Considering offensive speech act, the locutionary act is " They say a woman's work is never done. May be that's why they get paid less". The illocutionary force is asserting. Following Searle (1975) classification of speech acts, the speech act of this slogan is representative. Regarding felicity conditions, the propositional content condition is that women are paid less because they are less intelligence and slower than men in working. The preparatory condition, the designer of the slogan believes that he has the authority to criticize women or judging them. The circumstances of the slogan are offending, humiliating women and oppressing them by using offensive jokes. The sincerity condition, the designer of the slogan is sincere and serious in offending women by using jokes. The essential condition, the designer of this slogan has intends that his utterance must affect women negatively, to give a bad impression about women, and to hurt women by offending them with the intention of erasing their role gradually from the society. Moving the impoliteness following Culpeper (1996: 355-356), the slogan contain bold on record in which the slogan is impolite and offending without using any further impolite words and positive impoliteness in which the slogan attacks women's positive face by viewing them as unwanted, weak, foolish regarding the official jobs. Regarding Grice Maxims, the slogan designer follows the quantity maxim in being informative. The slogan follows relevance and manner maxims, since the massage of the slogan is relevant to the subject of humiliating women through using jokes and the slogan is also clear in its massage. The quality maxim is breached since the designer of the slogan does not have any evidence for his claim and he can be stating false information. The breach of the quality maxim contains an implicature which express that women are not qualified to work in any official work because they are incompetent and housekeeping as the picture suggests is the only suitable job for women. Finally, following Van Dijk's (1989) positive -self presentation and negative -other presentation, the slogan is polarized in to men 's positive self-presentation by showing them as intelligent, fast and able to work in an official work successfully and negative -self presentation by viewing women as less intelligent than men, slow, and unable to work in the official works.

\section{Analysis of the Fourth Slogan}

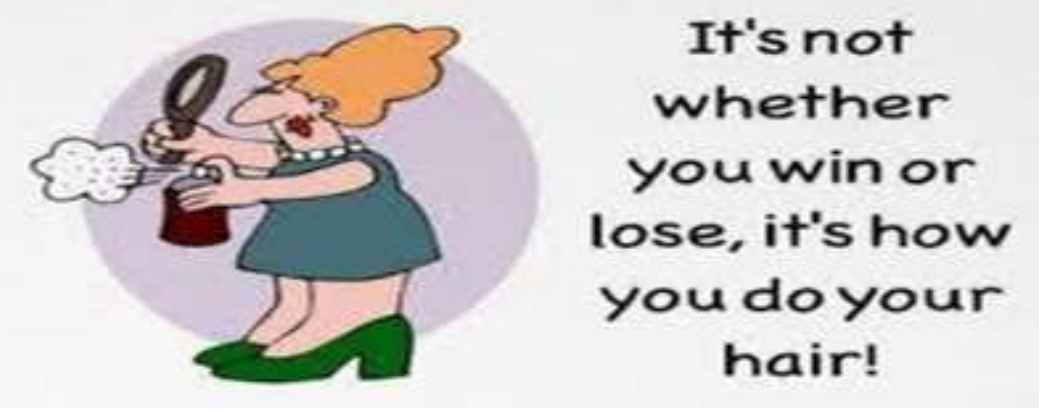

Starting with offensive speech act, the locutionary act is "It's not whether you win or lose, it's how you do your hair!". The illocutionary force is asserting. Following Searle (1975) classification of speech act, the speech act is assertive. Concerning felicity conditions, the propositional content condition is that the female speaker is asserting that winning or losing is not important but the important thing is the way you do your hair. Preparatory condition, the speaker is the designer of the slogan who has the authority to produce this offensive slogan and the circumstances of this speech act are offending women by showing that she cares for nothing except her appearance. The sincerity condition in which the designer of the slogan is serious and sincere in offending women. The essential condition in which the designer of the slogan intends that his offending joke affects woman' feeling negatively and make her offended and humiliated and also the designer of this slogan intends that this slogan be acted upon by women by accepting being inferior to men and with less social power in the society. Regarding politeness, following Culpeper (1996: 355-356), the designer of the slogan uses bold on record in which the message is impolite without using any extra words for making and positive politeness strategy in which women is represented as unwanted in the society because they care for nothing except their appearance. Moving to Grice Maxims, the slogan designer violate the quantity maxim since his message is not informative and it is too short. This violation carries an implicature that women are useless having no purpose or aim in life and care only for their appearance. The relevance maxim is also 
followed since the slogan is relevant to the subject matter of insulting women using jokes to view women as having no purpose in life and caring only for their appearance. The manner maxim is followed since the slogan is an ordered an a clear one. The quality maxim is violated since the slogan designer is not stating the truth and his assertion lacks evidence. Finally, dealing with ideological square, the designer of this slogan polarize his speech in to positive self-presentation and negative-other presentation. Women are viewed negatively by shedding light on the negative features and ignoring the positive features. Women are viewed as foolish who lacks the ability to have a purpose in life and women's good features like intelligence and resistance are hidden to present a negative view of women. This strategy is used to manipulate people's minds and naturalize the ideology that women can not have any role in the society.

\section{Analysis of the Fifth Slogan}

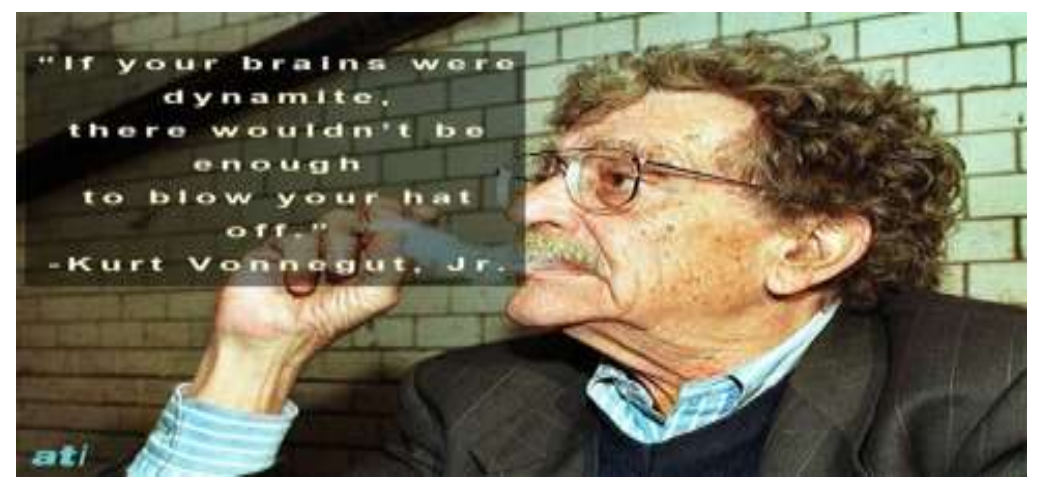

Dealing with offensive speech act, the locutionary act is " if your brains were dynamite. There wouldn't be enough to blow your hat off". The illocutionary force is asserting. According to Searle (1975) classification of speech act is assertive. Concerning felicity conditions, the propositional content condition is that Vonnegut asserts that women have no intelligence at all by comparing women brains to dynamite. The preparatory condition in which the speaker belief that he has the authority to describe women as foolish ones and the circumstances are of offending women using a joke that describe her as having no intelligence by comparing her intelligence to few amount of dynamite. The sincerity condition, Vonnegut is sincere and serious in describing women as having no intelligence at all which reflects his ideology as believing that women are inferior. The essential condition, Vonnegut intends that his insulting joke would affect women negatively by feeling insulted and offended and to acknowledge them that they are inferior to men in the society because of lacking intelligence. Regarding impoliteness, Vonnegut uses bold on record and positive politeness strategies. He uses bold on record in which the message is impolite without using any extra words for making the message more impolite and positive impoliteness strategy in which women are viewed as unwanted in the society because they are not intelligent and lacks mental abilities and skills. Regarding Grice Maxims, Vonnegut follows the quantity maxim in being informative. He also violates the quality maxim since he is not truthful or asserting something that he lacks evidence about. This violation carries in implicature that women are foolish and do not have any mental abilities. Finally, dealing with Van Dijk 's (1989) Ideological Square, Vonnegut's utterance is polarized in to positive-self presentation and negative other presentation. Women are presented negatively by shedding light only on their negative features and describing them with negatively by saying that they have no intelligence at all which leads to the naturalization and legitimation of men supremacy and women inferiority.

\section{Analysis of the Sixth Slogan}




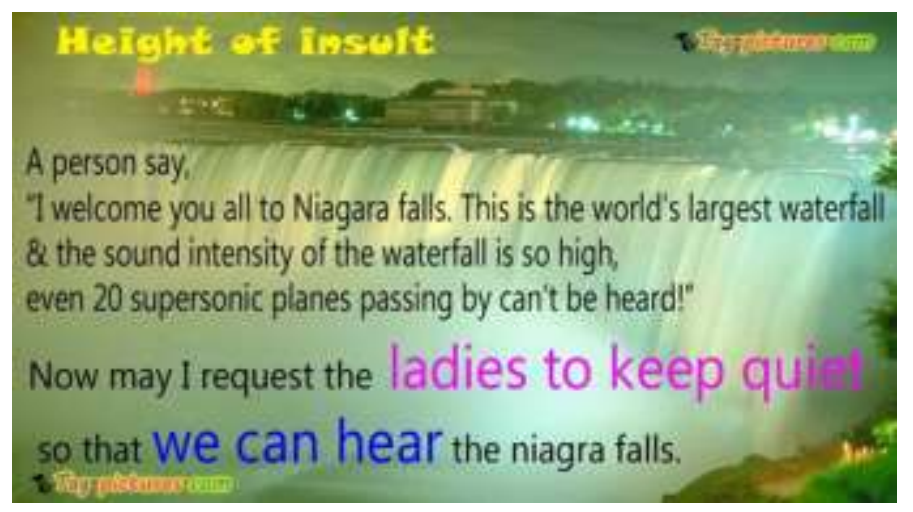

Regarding offensive speech act, the locutionary act is " A person says, "I welcome you all to Nigara falls. This is the world's largest waterfall \& the sound intensity of the waterfall is so high, even 20 supersonic planes passing by can't be heard! Now may I request the ladies to keep quiet so that we can hear the niagra falls. The illocutionary force is a request. Following Searle (1975) classification of speech act, this speech act is a directive one. Regarding felicity conditions, the propositional content condition is that the sounds of waterfall is so high but the ladies sound of chatting is higher and they need to keep quiet so people can hear the sound of the waterfall. The preparatory condition in which the designer of the slogan believe that he has the authority to criticize women as being talkative and the circumstances are of insulting women by exaggerating in describing them as talkative through stating that their sound is higher than a waterfall sound. The sincerity condition in which the designer of the slogan is sincere in offending women by describing her as talkative. The essential condition, the designer of the slogan intends that his insult would affect women negatively by feeling insulted and unwanted in the society. Dealing with politeness, following Culpeper (1996: 355-356), the designer of the slogan uses positive politeness strategy in which he the message is impolite by itself without using any extra strategies or words to make it more impolite. The designer of the slogan also uses negative impoliteness strategy in restricting women freedom by asking them to get quiet and positive impoliteness strategy in which women are viewed as talkative and unacceptable in the society. Dealing with Grice Maxims, the maxim of quantity is violated and this violation carry the implicature that women are talkative. The maxim of quality is violated since the designer of the slogan is saying something that he cannot be true and also lacks evidence. The maxims of manner and relevance are followed since the slogan is an ordered, organized and relevant to the subject matter of insulting women using jokes. Concerning Van Dijk's (1989) ideological square, this slogan is polarized in to positive-self presentation and negative other presentation. Women are viewed negatively by showing them as talkative and noisy and by ignoring all their positive features. Men are viewed positively as silent and intelligent. This strategy is used to persuade people and to naturalize the idea that women are second handed in the society and men must take the lead.

\section{Analysis of the Seventh Slogan}

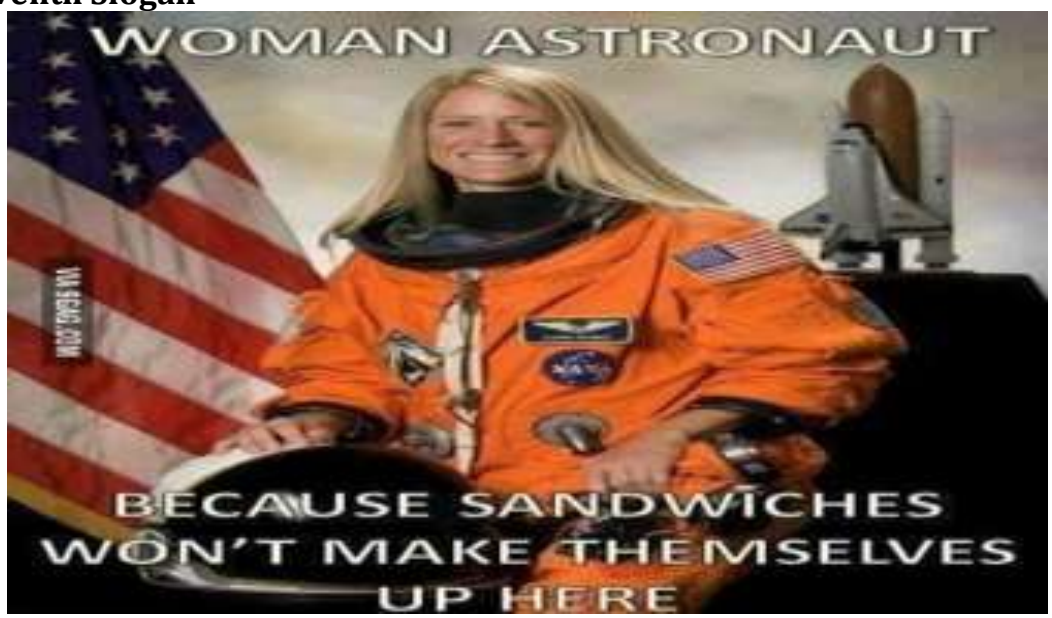


Regarding offensive speech act, the locutionary act is " Women Astronaut because Sandwiches won't make themselves up here. The illocutionary force is asserting. Following Searle (1975) the speech act is a representative one. Regarding felicity conditions, the propositional content condition, women work as an astronaut only to serve food to men in the space. The preparatory condition, the designer of the slogan believe that he has the authority to describe women as unable to do anything but house holding and cocking. The sincerity condition in which the designer of the slogan is sincere in insulting and humiliating women by viewing her as doing nothing in the space but cooking which imply that men are superior to women are inferior. The essential condition, the designer of the slogan intends that women get offended by this joke and naturalizing the idea in women's mind that men control the main jobs in the society while they are second handed to men. Following Culpeper (1996: 355-356), the designer of the slogan uses a number of impoliteness strategies that are negative impoliteness in which women' $s$ abilities and skills are limited to cooking, positive impoliteness strategy in which women are viewed as unwanted and unacceptable since they are unable to do anything accept cooking, and bold on record in which the message is impolite without using any other impolite words or strategies. Concerning Grice Maxims, the quantity maxim is followed since the message is informative. The maxim of quality is violated since women's work as astronauts is identified as doing nothing but cooking. The violation of this maxim carries an implicature that women are unsuitable for working in official work and she must be limited to house holding and cooking. The maxims of relevance and manner are followed since the message is ordered, organized and relevant to the subject matter of insulting women using jokes. Finally, regarding Van Dijk's (1989) ideological square, women are viewed negatively as unable to do any work that needs a mental activity and weak who are controlled by men.

\section{Analysis of the Eighth Slogan}

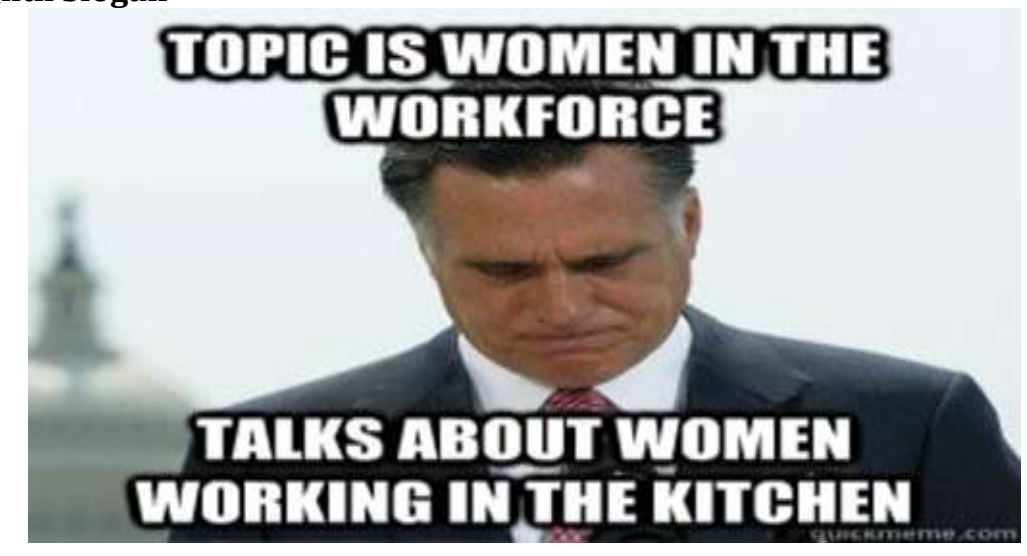

Considering offensive speech act, the locutionary act is " Topic is women in the workforce. Talks about women working in the kitchen. The illocutionary force is ordering. Following Searle (1975), this speech act is a directive one. Concerning felicity conditions, the propositional content condition is that the designer of the slogan describe women as working only inside the kitchen or her house. The preparatory condition, the designer of the slogan believe that he has the authority to classify women' only role in life is to be a housekeeper and the circumstances are of insulting women by limiting their abilities and skills to cooking and housekeeping instead of the work force. The sincerity condition, the designer of this slogan is sincere in offending and humiliating women by showing that they cannot have a role in the work force. The essential condition, the designer of this slogan intends that men become more powerful and dominant in the society by controlling the work force and the dominated group become less powerful and inferior by working only as housekeepers and for this ideology to be naturalized and legitimized in the society. Following Culpeper (1996: 355-356) in analyzing impoliteness, the designer of the slogan uses bold on record, positive and negative impoliteness strategies. The positive impoliteness strategy is used to view women as being weak, foolish and unable to have a role in the work force. The negative impoliteness is used to restrict women's freedom to house holding and limits her in the society. Bold on record is used since the message is impolite without using any extra words or strategies to make it more impolite. Concerning Grice Maxims, the quantity maxim is followed in this maxim since the message is informative. The quality maxim is breached since the designer of the slogan is not saying the truth and presenting false information. The violation of quality maxim carries the implicature that women are limited only to the work inside the house and cannot do anything in 
the work force. Also, maxims of manner and relevance are obeyed since the message is organized, ordered and relevant to the subject of insulting women by viewing them as able to cook but unable to be involved in the work force. Finally, dealing with Van Dijk's (1989), women are viewed negatively as having no role in the work force, ignoring their positive features and achievements in the work force.

\section{Analysis of the Ninth Slogan}

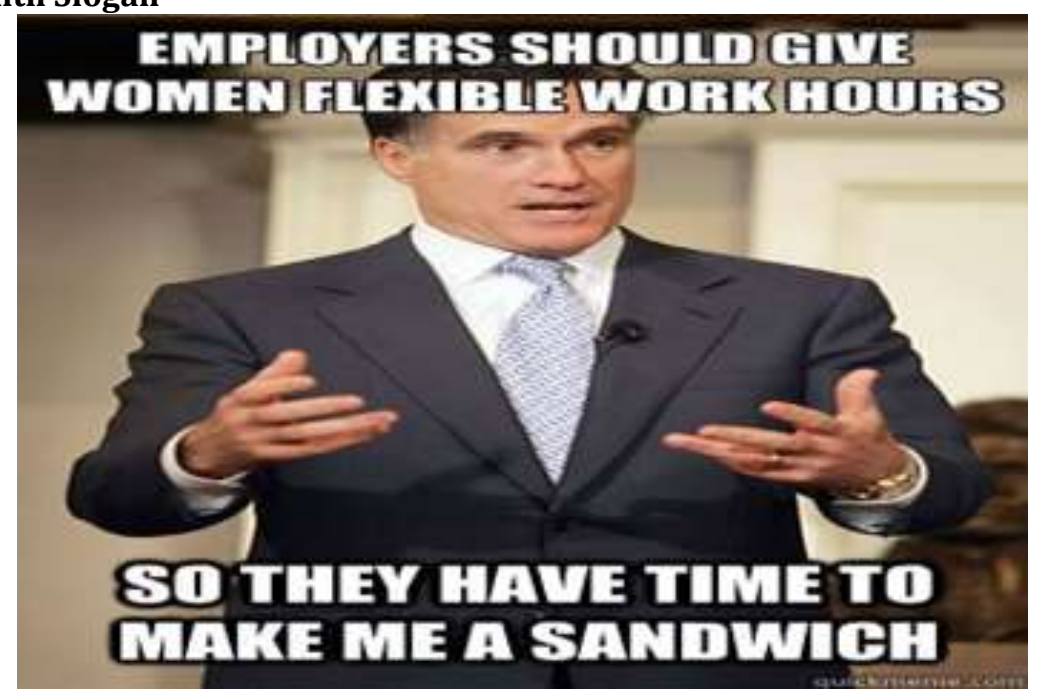

Dealing with offensive speech act, the locutionary act is " Employers should give women flexible work hours, so they have time to make me a sandwich". The illocutionary force is asserting. Following Searle (1975), this speech act is an assertive one. Dealing with felicity conditions, the propositional content condition is that the designer of the slogan is asserting that women must have little work hours so they have the time to make food for him and for men in general. The preparatory condition, the designer of this slogan is believe that he has the authority to limit and decrease women's role in official works and their work hours so they can serve men and the circumstances are of insulting women by giving them less work hours in order to serve men. The sincerity condition, the designer of the slogan is sincere in insulting using jokes that limits her to cooking for men rather than official work. The essential condition, the designer of the slogan intends that women get offended and humiliated by this joke. Following Culpeper (1996: 355-356), the designer of the slogan uses three strategies that bold on record in which the message is impolite without using any extra impolite words, positive impoliteness in which women are viewed as unacceptable in the official work and work force, and negative impoliteness strategies in which women are limited and restricted to house holding and cooking. Regarding Grice Maxims, quantity maxim is followed since the message is informative. The maxim of quality is violated since the slogan designer is not truthful regarding women working only in house holding. This violation carries an implicature that women do not have the ability to work for long hours and they can work only in house holding. Concerning Van Dijk's (1989) ideological square, women are presented negatively as weak, foolish, controlled by men and limited to minor aspects in society rather than the main ones while men are viewed as powerful, dominators, intelligent, and hard workers.

\section{Conclusion}

The present study reached the following conclusions. The designers of a number of slogans dealing with insulting jokes intend to oppress women using a number of linguistics strategies. They use offensive speech act that are mainly representatives, expressive and directives. The slogan designers use a number of different impoliteness strategies like negative, positive and bold on record strategies. Slogan designers of women insulting jokes follows are cooperative and follow relevance and manner maxims. Violations are related to quality and quantity maxims that carry implicatures. Implicature mainly expresses the idea that women are weak, foolish, unable to participate in official works, limited to house holding and cooking, caring only for the appearance and having no purpose in life. All of these strategies are used to present women negatively with all negative features and men positively with all positive features. The main aims of these slogans according to this study is to humiliate and offend women using insulting jokes. On a deeper level, these slogans intend to 
naturalize the ideology of women inferiority in the society and men superiority besides naturalizing and legitimizing women oppression and limitation in all aspects of life including work force. On a deeper level, they are designed mainly to increase men power and dominance and supremacy in the society with deceasing women's freedom, skills, and creativity besides being inferior and controlled by men and limiting women to house holding and other future career opportunities for men. This is done by manipulating the public minds by using mind control strategies so that even women will belief that this is the way the things should be. Finally, the present study recommends the deletion of such offensive slogans from the websites since they are seriously offending and reflect negative ideology and impression regarding women.

\section{References}

Al-Hindawi , M and Mohamad, W.S.M . (2018). Towards an Analytical Model in Critical Pragmatics. Arab World English Journal (AWEJ) Volume 9. Number 4. December 2018 https://dx.doi.org/10.24093/awej/vol9no4.11

Baker, P and Ellece, S. (2011). Key Terms in Discourse Analysis. London and New York: Continuum International Publishing Group

Culpeper, J. (1996). Towards an anatomy of impoliteness. In: Journal of Pragmatics 25 (3), 349-367.

Dickson M, Louis N (2018) Discrimination and Oppression of Women: A Social Work Exploration in Zimbabwe. Social Crimonol 6: 185. doi: 10.35248/2375-4435.18.6.185

Grice, H.P. (1967). Logic and Conversation. Unpublished MS. Of the William James Lectures: Harvard University.

Kaplan, B., R. (2010). The Oxford Handbook of Applied Linguistics' (2nd). New York: Oxford University Press. Korta, K and Perry, j (2011). Critical Pragmatics: An Inquiry into Reference and Communication. Cambridge University Press: Cambridge.

Kronman, A.T. (1983). Max Weber. London. Edward Arnold

Mateo , J \& Yus , F. (2000). Insults: A relevance-theoretic taxonomical approach to their translation. University of Alicante(Spain).

Mey, J. (2001). Pragmatics: An Introduction, 2nd ed. MA: Blackwell Publishing Searle, J.R. (1975). Indirect Speech Act. In Cole \& Morgan (1975): 59-82.

Van Dijk, T., A. (1998). Ideology: A Multidisciplinary Approach. London: Sage Publications Ltd.

Verschueren, J. (1999). Whose Discipline? Some Critical Reflections on Linguistic Pragmatics. Journal of Pragmatics, 31, 869-879.

Weber,M. (1925). Wirstchaft and Gesellschaft. Tubingen : JCB Mohr.

Widdowson , H.G ,. (2004). Text, Context, Pretext: Critical Issues in Discourse Analysis. USA: Blackwell Publishing.

Yule, G. (2000). Pragmatics. Oxford: Oxford University Press. 